\title{
Amorphous Mesoporous Iron Aluminophosphate Catalyst for the Synthesis of 1,5-Benzodiazepines
}

\author{
A. V. VIJAYASANKAR ${ }^{1}$, S. DEEPA ${ }^{1}$, B. R. VENUGOPAL ${ }^{2}$, N. NAGARAJU ${ }^{1, *}$ \\ ${ }^{1}$ Department of Chemistry, Catalysis Research Laboratory, St. Joseph's College Research Centre, \\ Shanthi Nagar, Bangalore 560027, India \\ ${ }^{2}$ Department of Organic Chemistry, Indian Institute of Science, Bangalore 560012, India
}

\begin{abstract}
A simple and versatile method for the synthesis of 1,5-benzodiazepines from $o$-phenylenediamine and ketones in the presence of solvents and under solvent-free conditions that used an amorphous mesoporous iron aluminophosphate as catalyst was developed. High yields with excellent selectivity were obtained with a wide variety of ketones under mild reaction conditions. The catalyst had the advantages of ease of preparation, ease of handling, simple recovery, reusability, non toxicity, and being inexpensive.

Key words: benzodiazepine; amorphous metal aluminophosphate; mesoporous iron aluminophosphate; o-phenylenediamine; ketone; solvent free synthesis
\end{abstract}

CLC number: O643

Document code: A

Benzodiazepines and their derivatives have broad and important pharmacological properties [1-4]. They are widely used as anticonvulsant, analgesic, hypnotic, sedative, and antidepressive agents. In addition, 1,5-benzodiazepines are key intermediates for the synthesis of various fused ring benzodiazepines derivatives [5-7]. Due to their wide biological, industrial, and synthetic applications [8-10], the synthesis of these compounds has received a great deal of attention. The general and simplest method to construct the ring skeletons of 1,5-benzodiazepine is the acid catalyzed reactions of $o$-phenylenediamines (OPDA) or $o$-aminothiophenol (o-ATP) with ketones, $\alpha, \beta$-unsaturated carbonyl compound, or $\beta$-haloketones [11,12].

Many of the synthesis methods of 1,5-benzodiazepines suffer from one or more limitations, such as long reaction times, occurrence of side reactions [13], severe reaction conditions, low yields, use of corrosive chemicals (e.g., $\mathrm{HCl}$ gas, trifluoroacetic acid) and hazardous reagents (e.g., pyridine, piperidine, halogenated hydrocarbon), high-boiling solvent (e.g., dimethylformamide), and tedious work-up procedures. Catalysts such as $\mathrm{BF}_{3}-\mathrm{Et}_{2} \mathrm{O}$ [14], $\mathrm{NaBH}_{4}$ [15], ceric ammonium nitrate [16], $\mathrm{PPA} / \mathrm{SiO}_{2}[17], \mathrm{MgO} / \mathrm{POCl}_{3}$ [18], $\mathrm{Yb}(\mathrm{OTf})_{3}$ [19], AcOH under microwave conditions [20], NBS [21], polymer-supported $\mathrm{FeCl}_{3} \mathrm{Sc}(\mathrm{OTf})_{3}$ [22], and ionic liquids [23] have been used to improve reaction efficiency. The main disadvantages of these catalysts are that they get lost in the work-up procedure, cannot be recovered or reused, and are highly toxic and expensive [24]. Therefore, a better catalyst for the synthesis of 1,5-benzadi- azepines is needed to achieve mild reaction conditions, operational simplicity, economic viability, and selectivity.

The use of heterogeneous catalysts such as $\mathrm{Al}_{2} \mathrm{O}_{3} / \mathrm{P}_{2} \mathrm{O}_{5}$ [25] and sulfated zirconia [26] is advantageous. The application of aluminophosphates as heterogeneous catalytic materials in organic synthesis is growing significantly. Our group has recently reported the catalytic activity of amorphous metal aluminophosphates as effective and recyclable materials in organic transformations [27-30]. To synthesize diazepines by an effective and environmentally benign route, we have condensed OPDA with various ketones in the presence of metal aluminophosphates as catalyst. This solvent-free protocol using a heterogeneous catalyst provides an excellent route for an eco-friendly and economic synthesis of benzodiazepines. We report for the first time a facile method for the synthesis of 1,5-benzodiazepines by the condensation of OPDA with ketones with an amorphous mesoporous iron aluminophosphate catalyst in the presence of a solvent and under solvent-free conditions.

\section{Experimental}

\subsection{Catalyst preparation}

The iron aluminophosphate (FeAlP) catalyst was prepared by co-precipitation [27-30]. Aluminum nitrate $\left(\mathrm{Al}\left(\mathrm{NO}_{3}\right)_{3} \cdot 9 \mathrm{H}_{2} \mathrm{O}\right)$, ferric nitrate $\left(\mathrm{Fe}\left(\mathrm{NO}_{3}\right)_{3} \cdot 9 \mathrm{H}_{2} \mathrm{O}\right)$, and $85 \%$ $\mathrm{H}_{3} \mathrm{PO}_{4}$ in a definite molar ratio (Al:Fe:P $\left.=0.95: 0.025: 1\right)$ were dissolved in $500 \mathrm{ml}$ of deionized water and stirred

Received date:. 6 April 2010.

*Corresponding author. Tel: +91-9886765750; Fax: +91-8022245831; E-mail: nagarajun@yahoo.com

English edition available online at ScienceDirect (http://www.sciencedirect.com/science/journal/18722067). 
vigorously. The solution was heated to $60-70{ }^{\circ} \mathrm{C}$, and then $28 \%$ ammonia was added continuously till a precipitate was obtained ( $\mathrm{pH}$ 9). The precipitate was filtered, washed with deionized water, dried at $120{ }^{\circ} \mathrm{C}$, and calcined at $550{ }^{\circ} \mathrm{C}$ for $5 \mathrm{~h}$. The obtained catalyst is denoted FeAlP-550.

\subsection{General procedure for the synthesis of 1,5-benzodizepines}

A mixture of OPDA (1 mmol) and ketone $(2.5 \mathrm{mmol}), 5$ $\mathrm{ml}$ of solvent (when used), and $0.2 \mathrm{~g}$ of catalyst were mixed in a $100 \mathrm{ml}$ round bottom flask and heated with stirring in a temperature controlled oil bath at $80{ }^{\circ} \mathrm{C}$ (Scheme 1). The progress of reaction was monitored by thin layer chromatography. The reaction mixture was treated with $1: 1(\mathrm{v} / \mathrm{v})$ water and $\mathrm{CH}_{2} \mathrm{Cl}_{2}$ and centrifuged to separate the solid catalyst. The organic layer was concentrated and the product was separated by silica gel (100-200 mesh) column chromatography using an ethyl acetate- $n$-hexane (2:8) mixture as eluent.<smiles>Nc1ccccc1N</smiles>

$o$-Phenylenediamine<smiles>[R]C([R])=O</smiles>

Ketones
FeAlP-550<smiles>[R]C1=Nc2ccccc2NC([R])([R])C1</smiles>

1,5-Benzodiazepines (a-l)

Scheme 1. Condensation of OPDA with ketones for the synthesis of 1,5-benzodiazepines.

\subsection{Characterization of product}

The yield and structure of the products were characterized by their melting point and FTIR, ${ }^{1} \mathrm{H}$ NMR, ${ }^{13} \mathrm{C}$ NMR, and mass spectrometry (MS). Melting points were recorded on an Electrothermal melting point apparatus. FTIR spectra were recorded using a Nicolet IR 200 instrument and the $\mathrm{KBr}$ pellet technique. ${ }^{1} \mathrm{H}$ and ${ }^{13} \mathrm{C}$ NMR spectra were recorded on a Bruker DSX-300 spectrometer at $300 / 400 \mathrm{MHz}$ and 75/100 MHz, respectively. Chemical shifts are reported downfield from tetramethylsilane (TMS). Multiplicity is indicated using the following abbreviations: $s$ (singlet), $d$ (doublet), dd (double doublet), t (triplet), m (multiplet), and bs (broad singlet). The mass spectra of the filtrate were recorded on an automated GC-MS Shimadzu QP 5000 GC-17A, EI-Mode Model.

Compound a: Yellow solid; mp $137-139{ }^{\circ} \mathrm{C}$; IR $(\mathrm{KBr}$, $\left.\mathrm{cm}^{-1}\right) v 3295,1633,1593,1437 ;{ }^{1} \mathrm{H} \mathrm{NMR}\left(\mathrm{CDCl}_{3}\right) \delta 1.35(\mathrm{~s}$, $\left.6 \mathrm{H}, 2 \mathrm{CH}_{3}\right), 2.23\left(\mathrm{~s}, 2 \mathrm{H}, \mathrm{CH}_{2}\right), 2.38$ (s, 3H, $\left.\mathrm{CH}_{3}\right), 2.98$ (br s, $1 \mathrm{H}, \mathrm{NH}), 6.74-7.27\left(\mathrm{~m}, 4 \mathrm{H}, \mathrm{C}_{6} \mathrm{H}_{4}\right) ;{ }^{13} \mathrm{C} \mathrm{NMR}\left(\mathrm{CDCl}_{3}\right) \delta$ $29.9,30.5,45.1,68.5,121.8,122.1,125.6,126.8,137.9$, 140.6, 172.5 .

Compound b: Yellow solid; mp $137-138{ }^{\circ} \mathrm{C}$; IR $(\mathrm{KBr}$, $\left.\mathrm{cm}^{-1}\right) v 3327,1635,1568,1442 ;{ }^{1} \mathrm{H}$ NMR $\left(\mathrm{CDCl}_{3}\right) \delta$ 0.95-1.66 (m, 6H, 2CH $), 1.71-2.13\left(\mathrm{~m}, 4 \mathrm{H}, \mathrm{CH}_{2}\right), 2.37$ (s, $3 \mathrm{H}, \mathrm{CH}_{3}$ ), 2.69 (q, 2H, $\mathrm{CH}_{2}$ ), 3.65 (br s, 1H, NH), 6.75-7.57 $\left(\mathrm{m}, 3 \mathrm{H}, \mathrm{C}_{6} \mathrm{H}_{3}\right) ;{ }^{13} \mathrm{C} \mathrm{NMR}\left(\mathrm{CDCl}_{3}\right) \delta 8.6,11.2,26.8,35.6$, $35.7,42.3,70.5,121.8,125.1,126.2,127.1,137.8,140.6$, 175.6 .

Compound c: Yellow solid; mp $144-145^{\circ} \mathrm{C}$; IR $(\mathrm{KBr}$, $\left.\mathrm{cm}^{-1}\right)$ v 3322, 1630, 1595; ${ }^{1} \mathrm{H}$ NMR $\left(\mathrm{CDCl}_{3}\right) \delta 0.73-1.65$ $\left(\mathrm{m}, 16 \mathrm{H}, 2 \mathrm{CH}_{2}\right.$ and $\left.4 \mathrm{CH}_{3}\right), 2.35-2.52\left(\mathrm{~m}, 2 \mathrm{H}, \mathrm{CH}_{2}\right), 2.85(\mathrm{q}$, $1 \mathrm{H}, \mathrm{CH}), 3.78$ (br s, $1 \mathrm{H}, \mathrm{NH}), 6.67-7.42\left(\mathrm{~m}, 4 \mathrm{H}, \mathrm{C}_{6} \mathrm{H}_{4}\right) ;{ }^{13} \mathrm{C}$ NMR $\left(\mathrm{CDCl}_{3}\right) \delta 7.5,7.8,11.5,12.2,28.1,28.3,35.5,46.1$,
68.9, 117.7, 118.1, 125.6, 132.7, 140.0, 142.4, 173.6.

Compound d: Yellow solid; mp $138-139{ }^{\circ} \mathrm{C}$; IR $(\mathrm{KBr}$, $\left.\mathrm{cm}^{-1}\right) v 3327,1620,1568,1430,1372 ;{ }^{1} \mathrm{H} \mathrm{NMR}\left(\mathrm{CDCl}_{3}\right) \delta$ $1.20-2.50\left(\mathrm{~m}, 15 \mathrm{H}, 7 \mathrm{CH}_{2}\right.$ and $\left.\mathrm{CH}\right), 3.90($ br s, $1 \mathrm{H}, \mathrm{NH})$, 6.55-7.77 (m, 4H, $\left.\mathrm{C}_{6} \mathrm{H}_{4}\right) ;{ }^{13} \mathrm{C} \mathrm{NMR}\left(\mathrm{CDCl}_{3}\right) \delta 23.1,24.3$, 24.5, 28.8, 33.5, 38.2, 39.2, 54.2, 67.1, 118.8, 119.2, 126.8, 132.1, 139.3, 143.4, 178.2.

Compound e: Yellow solid; mp $137-139{ }^{\circ} \mathrm{C}$; IR (KBr, $\left.\mathrm{cm}^{-1}\right) v 3322,1626,1568,1442,1365 ;{ }^{1} \mathrm{H}$ NMR $\left(\mathrm{CDCl}_{3}\right) \delta$ 0.85-2.36 (m, 19H, 9 $\mathrm{CH}_{2}$ and $\left.\mathrm{CH}\right), 3.48$ (br s, $\left.1 \mathrm{H}, \mathrm{NH}\right)$, 6.85-7.60 (m, 4H, $\left.\mathrm{C}_{6} \mathrm{H}_{4}\right) ;{ }^{13} \mathrm{C}$ NMR $\left(\mathrm{CDCl}_{3}\right) \delta 21.5,21.7$, $23.4,23.5,24.5,25.1,33.2,34.4,39.3,40.6,52.4,63.1$, 121.5, 126.4, 129.6, 138.2, 142.4, 178.5.

Compound f: Yellow solid; mp $136-137{ }^{\circ} \mathrm{C}$; IR $(\mathrm{KBr}$, $\left.\mathrm{cm}^{-1}\right) v 3328,1623,1550,1442,1360 ;{ }^{1} \mathrm{H}$ NMR $\left(\mathrm{CDCl}_{3}\right) \delta$ 1.15-2.45 (m, 19H, 9CH $\mathrm{CH}_{2}$ and $\left.\mathrm{CH}\right), 3.95$ (br s, $\left.1 \mathrm{H}, \mathrm{NH}\right)$, 6.52-7.70 (m, 4H, $\left.\mathrm{C}_{6} \mathrm{H}_{4}\right) ;{ }^{13} \mathrm{C} \mathrm{NMR}\left(\mathrm{CDCl}_{3}\right) \delta 22.7,23.1$, $24.3,24.5,27.2,28.1,33.5,34.3,38.2,39.2,54.2,55.4$, 67.1, 118.8, 119.2, 126.8, 132.1, 139.3, 143.4, 178.2 .

Compound g: Yellow solid; mp $151-152{ }^{\circ} \mathrm{C}$; IR $(\mathrm{KBr}$, $\left.\mathrm{cm}^{-1}\right) v 3332,1637,1598,1426 ;{ }^{1} \mathrm{H}$ NMR $\left(\mathrm{CDCl}_{3}\right) \delta 1.70(\mathrm{~s}$, $\left.3 \mathrm{H}, \mathrm{CH}_{3}\right), 2.95\left(\mathrm{~d}, 1 \mathrm{H}, \mathrm{CH}_{2}\right), 3.15\left(\mathrm{~d}, 1 \mathrm{H}, \mathrm{CH}_{2}\right), 3.35$ (br s, $1 \mathrm{H}, \mathrm{NH}), 6.65-7.10\left(\mathrm{~m}, 2 \mathrm{H}, \mathrm{C}_{6} \mathrm{H}_{4}\right), 7.25-7.48(\mathrm{~m}, 10 \mathrm{H}$, $\left.\mathrm{C}_{6} \mathrm{H}_{5}\right), 7.55-7.68\left(\mathrm{~m}, 2 \mathrm{H}, \mathrm{C}_{6} \mathrm{H}_{4}\right) ;{ }^{13} \mathrm{C} \mathrm{NMR}\left(\mathrm{CDCl}_{3}\right) \delta 29.7$, $41.4,74.3,121.6,122.0,125.4,126.7,127.3,127.4,128.3$, $128.5,128.8,129.6,138.1,139.2,140.6,145.3,166.3$.

Compound $\mathbf{h}$ : Pale yellow crystalline solid; mp 98-99 ${ }^{\circ} \mathrm{C}$; IR $\left(\mathrm{KBr}, \mathrm{cm}^{-1}\right) v 3318,1630,1598 ;{ }^{1} \mathrm{H}$ NMR $(300 \mathrm{MHz}$, $\left.\mathrm{CDCl}_{3}\right) \delta 1.72(\mathrm{~s}, 3 \mathrm{H}), 2.26(\mathrm{~s}, 3 \mathrm{H}), 2.32(\mathrm{~s}, 3 \mathrm{H}), 2.98(\mathrm{~d}$, $1 \mathrm{H}), 3.05$ (d, 1H), 3.43 (br s, 1H, NH), 6.74-6.76 (m, 1H), 6.98-7.02 (m, 6H), 7.21-7.23 (m, 1H), 7.47-7.50 (m, 4H); ${ }^{13} \mathrm{C} \mathrm{NMR}\left(75 \mathrm{MHz}, \mathrm{CDCl}_{3}\right) \delta 20.7,21.2,29.8,42.9,73.1$, $121.3,121.4,125.2,126.0,127.1,128.5,128.6,128.9$, $129.2,136.4,137.0,138.2,139.7,140.3,145.0,166.8$. 
Compound i: Yellowish solid; mp $114-116{ }^{\circ} \mathrm{C}$; IR (KBr, $\left.\mathrm{cm}^{-1}\right) v 3325,1135,1640,1594,1190 ;{ }^{1} \mathrm{H}$ NMR $(200 \mathrm{MHz}$, $\left.\mathrm{CDCl}_{3}\right) \delta 1.71(\mathrm{~s}, 3 \mathrm{H}), 2.85(\mathrm{~d}, 1 \mathrm{H}), 2.98(\mathrm{~d}, 1 \mathrm{H}), 3.73(\mathrm{~s}$, $3 \mathrm{H}), 3.77$ (s, 3H), 6.65-6.78 (m, 4H), 6.95-7.02 (m, 2H), 7.18-7.25 (m, 2H), 7.42-7.55 (m, 4H).

Compound j: Yellow crystalline solid; mp 219-220 ${ }^{\circ} \mathrm{C}$; IR $\left(\mathrm{KBr}, \mathrm{cm}^{-1}\right) v 3339,1636,1599 ;{ }^{1} \mathrm{H}$ NMR $(200 \mathrm{MHz}$, $\left.\mathrm{CDCl}_{3}\right) \delta 1.65(\mathrm{~s}, 3 \mathrm{H}), 2.77(\mathrm{~d}, 1 \mathrm{H}), 2.89(\mathrm{~d}, 1 \mathrm{H}), 4.18$ (br s, $\mathrm{NH}), 6.57-6.64(\mathrm{~m}, 4 \mathrm{H}), 6.81-7.00(\mathrm{~m}, 1 \mathrm{H}), 7.10-7.18(\mathrm{~m}$, 1H), 7.28-7.55 (m, 4H); ${ }^{13} \mathrm{C}$ NMR (75 MHz, $\left.\mathrm{CDCl}_{3}\right) \delta 29.2$, 42.0, 72.6, 114.4, 114.6, 120.5, 120.9, 124.9, 125.8, 127.0, 128.2, 130.0, 137.9, 139.5, 155.3, 158.6, 166.8.

Compound k: Yellow solid; mp $145-146{ }^{\circ} \mathrm{C}$; IR $(\mathrm{KBr}$, $\left.\mathrm{cm}^{-1}\right) v 3325,1640,1589,1198,574 ;{ }^{1} \mathrm{H}$ NMR (200 MHz, $\left.\mathrm{CDCl}_{3}\right) \delta 1.72(\mathrm{~s}, 3 \mathrm{H}), 2.87(\mathrm{~d}, 1 \mathrm{H}), 3.00(\mathrm{~d}, 1 \mathrm{H}), 2.65$ (br s, $\mathrm{NH}), 6.97-6.98(\mathrm{~m}, 1 \mathrm{H}), 7.00-7.04(\mathrm{~m}, 6 \mathrm{H}), 7.18-7.24(\mathrm{~m}$, 1H), 7.45-7.48 (m, 4H).

Compound I: Red crystalline solid; mp $156-158{ }^{\circ} \mathrm{C}$; IR $\left(\mathrm{KBr}, \mathrm{cm}^{-1}\right) v 3325,1642,1597 ;{ }^{1} \mathrm{H}$ NMR $(300 \mathrm{MHz}$, $\left.\mathrm{CDCl}_{3}\right) \delta 1.83(\mathrm{~s}, 3 \mathrm{H}), 2.96(\mathrm{~d}, 1 \mathrm{H}), 3.27(\mathrm{~d}, 1 \mathrm{H}), 3.52$ (br s, $\mathrm{NH}), 6.97-6.98(\mathrm{~m}, 1 \mathrm{H}), 7.00-7.02(\mathrm{~m}, 6 \mathrm{H}), 7.21-7.22(\mathrm{~m}$, 1H), 7.45-7.47 (m, 4H); ${ }^{13} \mathrm{C}$ NMR (75 MHz, $\left.\mathrm{CDCl}_{3}\right) \delta 30.0$, 42.9, 73.4, 121.3, 122.2, 123.5, 123.4, 126.8, 127.6, 127.7, $129.6,137.2,138.8,144.6,146.9,148.4,154.1,163.8$.

\section{Results and discussion}

\subsection{Effect of solvent in the condensation of OPDA and cyclohexanone}

Initially, a reaction between OPDA and cyclohexanone was carried out for the evaluation of FeAlP-550 as the catalyst under different reaction conditions (Table 1). In the first stage, the effect of solvent was studied using the different solvents of $\mathrm{CH}_{2} \mathrm{Cl}_{2}, \mathrm{H}_{2} \mathrm{O}, \mathrm{C}_{2} \mathrm{H}_{5} \mathrm{OH}, \mathrm{C}_{2} \mathrm{H}_{2} \mathrm{Cl}_{2}$, and $\mathrm{CHCl}_{3}$ as well as under solvent-free conditions. The reaction in the different solvents needed long reaction time and gave low yield. From among the tested solvents, ethanol was chosen as the solvent at $80^{\circ} \mathrm{C}$ (Table 1 , entry 3 ).

\subsection{Catalyst screening}

Although the target catalyst was iron aluminophosphate, the catalytic activity studies were also conducted using hydrated alumina $\left(\mathrm{Al}(\mathrm{OH})_{3}\right)$, aluminium phosphate (AlP), iron phosphate $(\mathrm{FeP})$, and hydrated iron oxide $\left(\mathrm{Fe}_{2} \mathrm{O}_{3} \cdot x \mathrm{H}_{2} \mathrm{O}\right)$ calcined at 120 and $550{ }^{\circ} \mathrm{C}$. This was because the preparation of iron aluminophosphate by the procedure followed in the present work had the possibility of the formation of these materials along with iron aluminophosphate. Hence, we also wanted to characterize the catalytic activity, if any, of these materials.
Table 1 Optimization of solvent conditions for the reaction of OPDA and cyclohexanone using FeAlP-550 as catalyst

\begin{tabular}{cccc}
\hline Entry & Temperature $\left({ }^{\circ} \mathrm{C}\right)$ & Solvent & Yield $^{*}(\%)$ \\
\hline 1 & 50 & dichlolromethane & 60 \\
2 & 100 & water & 20 \\
3 & 80 & ethanol & 94 \\
4 & 85 & dichloroethane & 69 \\
5 & 65 & chloroform & 57 \\
\hline
\end{tabular}

* Isolated yield.

The catalytic activity of the various materials expressed as the percentage of isolated yield of product in the condensation of OPDA and cyclohexanone is presented in Table 2. The condensation reaction did not give much yield of the expected product in the absence of a catalyst. The reaction was very slow with only traces of products in the absence of a catalyst. All the materials were found to be active for the condensation reaction between OPDA and cyclohexanone in the presence of ethanol as solvent. There was not much difference in their catalytic activity and the effect of the temperature of calcination, except in the case of iron aluminophosphate. FeAlP calcined to $550{ }^{\circ} \mathrm{C}$ exhibited excellent catalytic activity and resulted in the best isolated yield of diazepines.

Table 2 Effect of catalyst under different reaction conditions for the condensation of OPDA and cyclohexanone

\begin{tabular}{ccc}
\hline Entry & Catalyst & Yield $^{\mathrm{a}}(\%)$ \\
\hline 1 & blank & trace $^{\mathrm{b}}$ \\
2 & $\mathrm{Al}(\mathrm{OH})_{3}-120$ & 30 \\
3 & $\mathrm{Al}(\mathrm{OH})_{3}-550$ & 25 \\
4 & $\mathrm{AlP}-120$ & 54 \\
5 & $\mathrm{AlP}-550$ & 58 \\
6 & $\mathrm{FeP}-120$ & 68 \\
7 & $\mathrm{FeP}-550$ & 70 \\
8 & $\mathrm{Fe}(\mathrm{OH})_{3}-120$ & 65 \\
9 & $\mathrm{Fe}(\mathrm{OH})_{3}-550$ & 69 \\
10 & $\mathrm{FeAlP}-120$ & 70 \\
11 & $\mathrm{FeAlP}-550$ & 94 \\
\hline
\end{tabular}

Reaction conditions: diamine $1 \mathrm{mmol}$, ketone $2.5 \mathrm{mmol}$, catalyst $0.3 \mathrm{~g}$ in $5 \mathrm{ml}$ of ethanol, $80^{\circ} \mathrm{C}, 120 \mathrm{~min}$.

${ }^{\mathrm{a}}$ Isolated yield.

${ }^{\mathrm{b}}$ Isolated yield after $10 \mathrm{~h}$.

\subsection{Efficiency of catalyst under solvent-free conditions at different temperatures}

The reaction was further investigated under solvent-free conditions at different temperatures in the presence of the active FeAlP-550 catalyst. The reaction did not proceed rapidly at room temperature (rt) under solvent-free conditions. However, the yield after $2 \mathrm{~h}$ was found to be $50 \%$ (Table 3 ). When the reaction was allowed to continue for 10 
Table 3 Effect of reaction temperature for the condensation of OPDA and cyclohexanone under solvent-free conditions using FeAlP-550 as catalyst

\begin{tabular}{ccc}
\hline Entry & Temperature $\left({ }^{\circ} \mathrm{C}\right)$ & Yield $^{\mathrm{a}}(\%)$ \\
\hline 1 & $\mathrm{rt}$ & 50 \\
2 & 54 & 78 \\
3 & 80 & 96 \\
4 & $\mathrm{rt}$ & $85^{\mathrm{b}}$ \\
\hline
\end{tabular}

Reaction conditions: diamine $1 \mathrm{mmol}$, ketone $2.5 \mathrm{mmol}$, catalyst $0.2 \mathrm{~g}$, $120 \mathrm{~min}$.

${ }^{\mathrm{a}}$ Isolated yield.

${ }^{\mathrm{b}}$ Isolated yield after $10 \mathrm{~h}$.

$\mathrm{h}$, a product yield of $85 \%$ was achieved. When the reaction temperature was increased, a higher yield of diazepines of $96 \%$ was obtained at $80{ }^{\circ} \mathrm{C}$. The yield was a function of temperature under solvent-free conditions. An optimum temperature of $80{ }^{\circ} \mathrm{C}$ was required for a better yield, which is explained in the mechanism (Scheme 2). This gave a sufficient number of ketones available on the surface of the catalyst to propagate the reaction.

\subsection{Reusability of catalyst in the condensation of OPDA and cyclohexanone}

We also investigated the reusability of the FeAlP-550 catalyst, both in the presence of ethanol and under solvent-free conditions. The catalyst was recovered by dissolving the reaction mixture in $1: 1(\mathrm{v} / \mathrm{v})$ water and $\mathrm{CH}_{2} \mathrm{Cl}_{2}$ and filtered to separate the solid catalyst. The catalyst was separated by simple filtration, washed with acetone, dried at $120{ }^{\circ} \mathrm{C}$, and calcined at $550{ }^{\circ} \mathrm{C}$. The catalyst was reused at least four times in the same reaction without appreciable loss in catalytic activity. The results of the reusability of the catalyst are shown in Table 4.
Table 4 Synthesis of benzodiazepines using FeAlP-550 as an efficient and reusable catalyst

\begin{tabular}{ccc}
\hline Cycle & Yield $^{\mathrm{a}}(\%)$ & Yield $^{\mathrm{b}}(\%)$ \\
\hline 1 & 96 & 94 \\
2 & 90 & 88 \\
3 & 43 & 85 \\
4 & 20 & 69 \\
\hline
\end{tabular}

${ }^{\text {a } I s o l a t e d ~ y i e l d ~ i n ~ t h e ~ a b s e n c e ~ o f ~ s o l v e n t s . ~ R e a c t i o n ~ c o n d i t i o n s: ~ d i a m i n e ~}$ $1 \mathrm{mmol}$, ketone $2.5 \mathrm{mmol}$, catalyst $0.3 \mathrm{~g}, 80^{\circ} \mathrm{C}$.

${ }^{\mathrm{b}}$ Isolated yield in the presence of solvent (ethanol). Reaction conditions: diamine $1 \mathrm{mmol}$, ketone $2.5 \mathrm{mmol}$, catalyst $0.2 \mathrm{~g}$ in $5 \mathrm{ml}$ ethanol, $80{ }^{\circ} \mathrm{C}$.

\subsection{Synthesis of benzodiazepines both in the presence of ethanol as solvent and under solvent-free conditions}

To look at the application of FeAlP as a general catalyst for the synthesis of 1,5-benzodiazepines, the condensation reactions under optimized conditions using a variety of aliphatic, alicyclic ketones, and substituted acetophenones were carried out. The results are presented in Table 5. All the ketones condensed smoothly with OPDA in the presence of FeAlP-550 without forming any side products. The only noticeable difference in the reactivity of the various ketones was in the time taken to get a significant yield of the expected diazepine products. It is noteworthy that the condensation of the various ketones with OPDA in the presence of FeAlP-550 was superior in terms of yield and selectivity for products as compared to other catalysts reported in the literature.

Under the optimum conditions, aliphatic ketones gave a product yield in the range of $87 \%-94 \%$ after $45 \mathrm{~min}$, which depended on the nature of the ketone. Cyclic ketones such as cyclohexanone, cycloheptanone, and cyclopentanone (Table 5, entries 4-6) also produced the corresponding

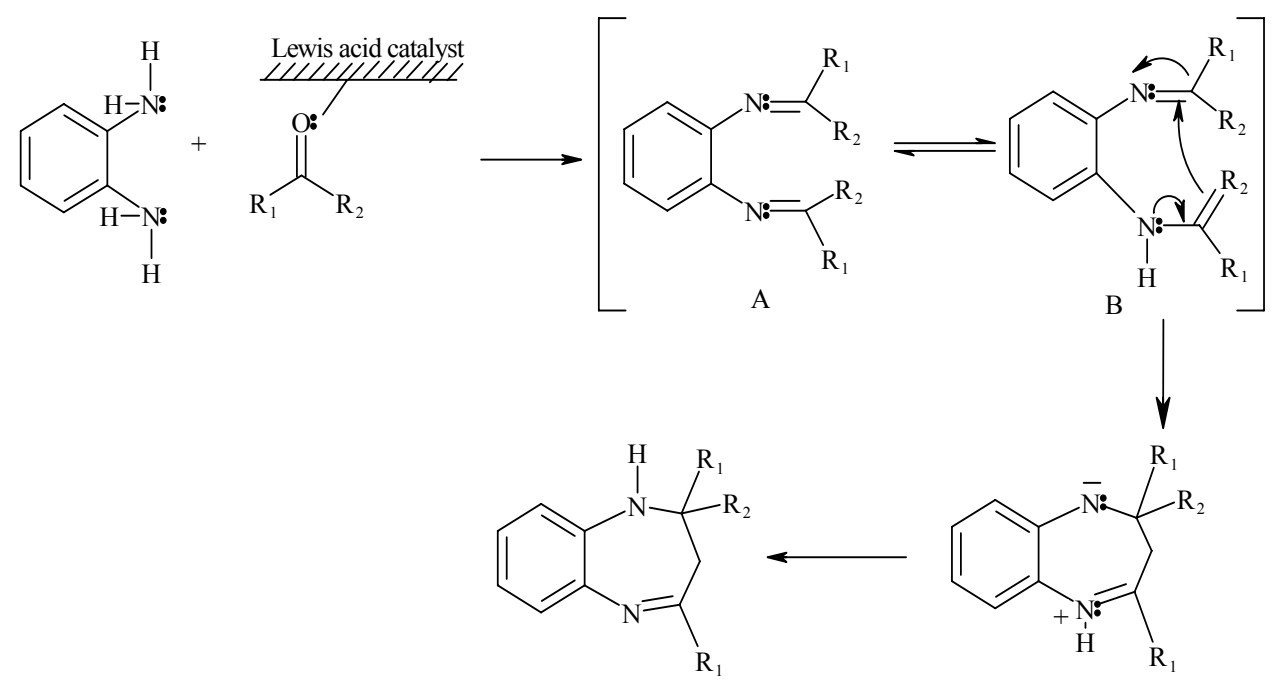

Scheme 2. Mechanism for the condensation of OPDA and ketones over a FeAlP-550 catalyst. 
Table 5 Condensation of OPDA and ketones catalyzed by FeAlP-550 catalyst under different reaction conditions

\begin{tabular}{|c|c|c|c|c|c|c|c|c|}
\hline \multirow{2}{*}{ Entry } & \multirow{2}{*}{ Ketone } & & \multirow{2}{*}{ Diazepine derivative } & \multirow{2}{*}{ Time (min) } & \multirow{2}{*}{ Yield $^{\mathrm{a}}(\%)$} & \multirow{2}{*}{ Yield $^{\mathrm{b}}(\%)$} & \multicolumn{2}{|c|}{ Melting point $\left({ }^{\circ} \mathrm{C}\right)$} \\
\hline & & & & & & & Expt. & Reported \\
\hline 1 & & & & 45 & 94 & 94 & 140 & $137-139$ \\
\hline 2 & & & & 45 & 95 & 88 & 140 & $137-138$ \\
\hline 3 & & & & 45 & 90 & 87 & 140 & $144-145$ \\
\hline 4 & & & & 120 & 89 & 81 & 137 & $138-139$ \\
\hline 5 & & & & 120 & 94 & 96 & 139 & $137-139$ \\
\hline 6 & & f & & 120 & 83 & 68 & 135 & $136-137$ \\
\hline 7 & & & & 75 & 92 & 90 & 152 & $151-152$ \\
\hline 8 & & & & 120 & 89 & 87 & 99 & 143 \\
\hline 9 & & & & 120 & 85 & 84 & 117 & $114-116$ \\
\hline 10 & & & & 80 & 84 & 81 & 217 & $219-220$ \\
\hline 11 & & & & 80 & 83 & 85 & 146 & $145-146$ \\
\hline 12 & & 1 & & 80 & 86 & 85 & 157 & $156-158$ \\
\hline
\end{tabular}

Reaction conditions: diamine $1 \mathrm{mmol}$, ketone $2.5 \mathrm{mmol}$, catalyst $0.3 \mathrm{~g}$ in $5 \mathrm{ml}$ ethanol or $0.2 \mathrm{~g}$ in solvent-free conditions, $80^{\circ} \mathrm{C}$.

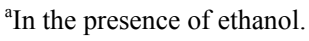

${ }^{\mathrm{b}}$ Under solvent free conditions.

fused-ring benzodiazepines in good yields but after a longer time ( $120 \mathrm{~min})$ as compared to the aliphatic ketones (Table 5 , entries 1-3).

The condensation activity of acetophenones and its derivatives was found to be better than that of cyclic ketones.
The reactivity depended on the substituent on the benzene. In the presence of electron withdrawing groups such as $-\mathrm{OH},-\mathrm{Br}$, and $-\mathrm{NO}_{2}$, the condensation reaction proceeded smoothly to give good yields of benzodiazepines (Table 5, entries 10-12). Whereas the presence of electron releasing 
groups such as methyl and methoxy groups on the benzene nucleus of acetophenone only gave poor yields (Table 5 entries 8 and 9) of benzodiazepines even after long reaction times.

\subsection{Mechanism for the condensation of OPDA and ketones over FeAIP-550 catalyst}

From the above observations on the reactivity of various ketones in the presence of FeAlP-550 as the catalyst, we propose the reaction mechanism shown in Scheme 2. The catalyst FeAlP-550 has surface acid sites. The oxygen atom of the ketones is adsorbed through its lone pair electrons on the surface acid sites of the catalyst, and the amino groups of OPDA attack the carbonyl group of the ketone to give the intermediate diimine (A and B). A 1,3-hydrogen shift to the attached methyl group then occurred to form an isomeric enamine, which cyclizes to afford the seven-member ring. An alternative mechanism involving the aldol condensation of ketones to give $\alpha, \beta$-unsaturated carbonyl compound which subsequently undergoes 1,4-addition was ruled out because such an aldol condensation does not occur in ketones with a $\alpha$-hydrogen in the presence of FeAlP. The reaction conditions are mild and no side products or decomposition of the products were observed.

The better catalytic activity of FeAlP-550 over that of the other catalysts reported may be attributed to its mesoporous texture and amorphous nature, which gave a higher concentration of active acid sites on its surface [30]. We have previously reported a correlation between the textural/structural properties and catalytic activity of these materials in organic transformations like tranesterification and alkylation reactions [28,29]. Since larger crystallites have only a small percentage of the reactive sites on the surface, smaller crystallites or amorphous materials possess a much higher surface concentration of sites, and it is this morphological difference that makes FeAlP an efficient catalyst.

\subsection{Advantages of the FeAIP-550 catalyst}

The catalyst preparation is simple and involves readily available non-hazardous and inexpensive reagents. The separation of the product from the reaction mixture does not require any tedious workup procedure. The recovered catalyst can be reused at least four to five times (Table 4) without any significant loss in activity. Thus, the present data showed the efficient reusability of the catalyst. As compared to other acid catalysts reported in the literature, iron aluminophosphate was superior in terms of a higher conversion, short reaction time, and small amount of catalyst needed. Also, this method does not require any expensive reagents or special care to exclude moisture from the reac- tion medium.

\section{Conclusions}

Iron aluminophosphate was a highly efficient heterogeneous, recyclable catalyst for the synthesis of 1,5-benzodiazepines by the condensation of OPDA with a wide variety of ketones. This method has easy workup, solvent-free conditions, fast reaction rate, good yields, and high selectivity, which make it attractive for large scale operations. This method is effective for the preparation of 1,5-benzodiazepines from both electron-rich and electron-deficient ketones and $o$-phenylenediamine derivatives under mild reaction conditions. The activity of the catalyst was attributed to its amorphous mesoporous nature and surface acid sites that allowed the reaction to be completed in a short time with high yield and $100 \%$ selectivity for the desired product.

\section{Acknowledgments}

We thank NMR centre, Indian Institute of Science, Bangalore, India, for NMR analysis and Mr. Prasad, Anthem biosciences, Bangalore, India, for GC-MS analysis.

\section{References}

1 Krapcho J, Turk C F. J Med Chem, 1966, 9: 191

2 Randall L O, Kamel B. In: Garattini S, Mussini E, Randall L O eds. Benzodiazepines. New York: Raven Press, 1973. 27

3 Schultz H. Benzodizepines. Heidelberg: Springer, 1982

4 Landquist J K. In: Katritzky A R, Rees C W eds. Comprehensive Heterocyclic Chemistry. Oxford: Pergamon, 1984. 166

5 Essaber M, Baouid A, Hasnaoui A, Benharref A, Lavergne J P. Synth Commun, 1998, 28: 4097

6 El-Sayed A M, Abdel-Ghany H, El-Saghier A M M. Synth Commun, 1999, 29: 3561

7 Reddy K V V, Rao P S, Ashok D. Synth Commun, 2000, 30: 1825

8 Haris R C, Straley J M. US 1537 757. 1968

9 Heravi M M, Motamedi R, Siefi N, Bamoharram F F. J Mol Catal A, 2006, 249: 1

10 Gringauz A, Introduction to Medicinal Chemistry. New York: Wiley-VCH, 1999

11 Ried W, Stahlhofen P. Chem Ber, 1957, 90: 815

12 Ried W, Torinus E. Chem Ber, 1959, 92: 2902

13 Chaudhari M K, Hussaina S. J Mol Catal A, 2007, 269: 214

14 Herbert J A L, Suschitzky H. J Chem Soc, Perkin Trans, 1974, 1: 2657

15 Morales H R, Bulbarela A, Contreras R. Heterocycles, 1986, 24: 135

16 Varala R, Enugala R, Nuvula S, Adapa S R. Synlett, 2006, 7: 1009 
17 Jung D I, Choi T W, Kim Y Y, Kim I S, Park Y M, Lee Y G Jung D H. Synth Commun, 1999, 29: 1941

18 Balakrishna M S, Kaboudin B. Tetrahedron Lett, 2001, 42: 1127

19 Curini M, Epifano F, Marcotullio M C, Rosati O. Tetrahedron Lett, 2001, 42: 3193

20 Pozarentzi M, Stephaniclou-Stephanatou J, Tsoleridis C A. Tetrahedron Lett, 2002, 43: 1755

21 Kuo C W, More S V, Yao C Y. Tetrahedron Lett, 2006, 47: 8523

22 Chari M A, Syamasundar K. Catal Commun, 2005, 6: 67
23 Jarikote D V, Siddiqui S A, Rajagopal R, Daniel T, Lahoti R J, Srinivasan K V. Tetrahedron Lett, 2003, 44: 1835

24 De S K, Gibbs R A. Tetrahedron Lett, 2005, 46: 1811

25 Kaboudin B, Navaee K. Heterocycles, 2001, 55: 1443

26 Reddy B M, Sreekanth P M. Tetrahedron Lett, 2003, 44: 4447

27 Nagaraju N, Kuriakose G. New J Chem, 2003, 27: 765

28 Nagaraju N, Kuriakose G. Green Chem, 2002, 4: 269

29 Kuriakose G, Nagy J B, Nagaraju N. Catal Commun, 2005, 6: 29

30 Vijayasankar A V, Anis C U, Nagaraju N. J Korean Chem Soc, 2010, 54: 131 